\title{
CREATING AN ENGLISH MATERIALS IN ORAL DISCOURSE ASPECT FOR THE TAXI DRIVERS
}

\author{
Dewa Ayu Kadek Claria \\ Universitas Warmadewa \\ claria@warmadewa.ac.id
}

\begin{abstract}
This research was concerned in creating an English material in oral discourse aspect for the Taxi Drivers. The research conducted based on the problems faced by the taxi drivers in the tourism object which need English as a main language in communicating with the international passenger. The improvement in English skill especially in oral discourse for the taxi drivers was aimed to provide a better service in their job which runs in tourism field. The method used in conducting the research consists of three steps; they are chose the data source, collect the data, and analyse the data. The data was taken by doing the interview and spread the questionnaire to the taxi drivers in Sanur. The material selection was done by selecting the most difficult aspect that the drivers thought in learning English especially in oral discourse aspect. The analysed data provide the basis in creating an English material for the drivers. The theory applied in this research are theory of Hutchinson and Waters in their book entitled English for Specific purpose (1987) as the main theory and the theory of Van Dijk (1993) in his book entitled Principles od Discourse analysis and Searle, J. R. (1696) in her book entitled Speech Acts, an essay in the philosophy of language as supporting theories. As the result, the English materials was created based on Hutchinson and Waters theory which consists of input, content focus, language focus and task. Those model of learning was the most suitable to the taxi driver seen from the layout and also the English material has more specific material organization by applied this model.
\end{abstract}

Keywords: English materials; oral discourse; speech acts; taxi driver

\section{INTRODUCTION}

Bali is categorized as one of the most favourite tourist destinations in the world. Bali is a small island that has attracted a lot of foreigners with the ancient culture, historical places, beautiful nature, and also the Balinese people with their warm hospitality. As tourist destination, the accommodations, entertainments, transportation and other things which related to the tourism becomes the need. All those sectors grow with the demands that the English skills plays an important rule in communication which is in line with the development of the city.

Transportation can be said that it takes a part as the first impression of Bali. When the tourist come to Bali, they need transportation in their first list. The easiest transportation that the tourist can be afforded when they arrive at the airport or to go somewhere is taxi. The taxi drivers have to speak fluently in English since the drivers are involved directly in communicating with the tourists especially for the foreigner. The communication between the driver and passenger sometimes become something difficult because of the lack ability of the driver in speaking English. In fact, the driver in doing their job need to speak English very well in order to perform the job better and also to keep the best impression of Bali.

Communication always related with language. Language has functions as a tool of communication that is used by people in every activity. Language has an important to deliver what people think and to achieve what is speaker aim. Communicate by using language which is not our first language is quite difficult and in this case is when the taxi drivers try to communicate by using English with the passenger. Communication works when the interaction happen or simply means when 
people can maintain the topic for long time in the conversation.

According to Suwandi, office, market, in teaching process and also in some business fields (Suwandi, 2008: 97). The interaction is categorized as discourse because the interaction always has a same background but different social meaning. Oral discourse is the action happen where people do an interaction orally. The interaction happen between the drivers and passenger in the business is part of oral discourse. Idat has a different point of view. He said that discourse describes the whole utterances which having a meaning and stated that the language plays as a tool to understand spoken discourse which utter by the speaker (Idat, 1994: 4).

Other aspects that cause the driver do not want to improve their speaking skills are that the drivers have lack motivation to improve their English due to their age, the working time which impossible for them to leave the job only to take the course in the class and the lack of the books which consists of the English materials specific for the taxi drivers. According to Kamaruddin in her research said that taxi service is become trend and popular lately in all over the world so that the problems faced by those drivers in communicating also grow up in line with the popularity (Kamarudin Siti \& Izehari, 2017: 45). She categorized three main challenges faced by the drivers which are struggle to comprehend language in English with native speaker, difficulty to make the conversation keep going and also difficulty to speak with international passenger who were non native but try to communicate by using English as International language.

By all those problems, the English materials was designed based on Hutchinson and Waters' model (1987) and also completed with oral discourse aspects by Van Dijk (1993). The material was focused on the need of the taxi drivers who worked at tourism area in Sanur Bali. This research has the objective to improve the English competency of the taxi drivers especially to make a communicative communication using English with foreigners. By creating the material for the taxi drivers, they are train to improve their communication skills therefore in the end the taxi drivers should be able to use English fluently in communication.

\section{METHOD}

The methodology applied in this research is descriptive qualitative. The method used in conducting this research consists of three steps; they are chose the data source, collect the data, and analyse the data. The data was taken by doing the interview and spread the questionnaire to the taxi drivers in Sanur, so in other words the sources of this research come from the taxi drivers based in Sanur. Meanwhile the data collection done by observation, interview and questionnaire. After the data was collected, the material selection was done by selecting the most difficult aspect that the drivers thought in learning English especially in oral discourse aspect. The analysed data provide the basis in creating an English material for the drivers.

\section{DISCUSSION}

\section{Hutchinson and Waters' Model}

In creating any learning materials always related to the need as the main purpose. According Hutchinson and Waters, the understanding of need in relation to create the English material is the ability to comprehend and produce the linguistic features of the target situation (Hutchinson \& Waters, 1987: 54). There are two kinds of basic needing in creating material namely target need and learning need. The components in target need consist of necessities, lacks, and wants. Necessities are what the learner has to know effectively for the specific or target situation. Lacks is what the learner have not know and wants is the learner view of the necessities in the target situation. The other basic need is learning need. Learning need is the ability and knowledge that the learner should have in order to be able to perform the require competence in specific situation.

From the explanation about needs, it can be seen that the need analysis is conducted first by spreading the questionnaire to know the taxi driver strength and weakness of their English proficiency especially in oral discourse or the other problems that cause the taxi drivers find it difficult to improve their competency in 
English. The result from the questionnaire and interview can be seen as below.

Table 1 Taxi Drivers' Strengths and Weaknesses in English Proficiency

\begin{tabular}{lcccc}
\hline Skills & $\begin{array}{c}\text { Very } \\
\text { Weak }\end{array}$ & Weak & Good & $\begin{array}{c}\text { Very } \\
\text { Good }\end{array}$ \\
\hline Grammar & $20 \%$ & $75 \%$ & $5 \%$ & $0 \%$ \\
Vocabulary & $10 \%$ & $65 \%$ & $20 \%$ & $5 \%$ \\
Pronunciation & $25 \%$ & $60 \%$ & $10 \%$ & $5 \%$ \\
Listening & $20 \%$ & $50 \%$ & $20 \%$ & $10 \%$ \\
Speaking & $25 \%$ & $35 \%$ & $25 \%$ & $15 \%$ \\
Reading & $20 \%$ & $60 \%$ & $15 \%$ & $5 \%$ \\
Writing & $20 \%$ & $75 \%$ & $5 \%$ & $0 \%$ \\
\hline
\end{tabular}

From the table above, it can be seen that the ability of the taxi drivers in English proficiency is various. In some aspects such as speaking and pronunciation the taxi drivers still in "weak" category which means that the skills in this aspect still need to be improved. The grammar aspect also needs attention since from the percentage all the drivers could not use the grammar correctly. The drivers also need to improve their vocabulary because they can not use vocabulary while driving. The drivers have to add in their mind at least five new words everyday. It can be seen by the data that not all the drivers place in a good category. Listening skill also become so important in this matter since the drivers have to communicate with the guest and maintain them into conversation. The ability as a hearer to understand what speaker says and then continue by produce something related to the topic as speaker in the key for a good communication. The other problems that cause the taxi drivers won't be able to improve the competency are their social or personal matter as below.

Table 2 The Personal Matter Intervene the English Improvement

\begin{tabular}{clcc}
\hline No & \multicolumn{1}{c}{ Problems } & Yes & No \\
\hline 1 & $\begin{array}{l}\text { The basic skills of } \\
\text { English }\end{array}$ & 8 \\
2 & $\begin{array}{l}\text { Age factor that decreased } \\
\text { the learning ability } \\
\text { The ability to use } \\
\text { technology as learning } \\
\text { media }\end{array}$ & 6 & 3 \\
$4 \quad \begin{array}{l}\text { The lack of money to } \\
\text { join a course }\end{array}$ & 8 & 2 \\
5 & $\begin{array}{l}\text { Working time schedule } \\
\text { which is unpredictable }\end{array}$ & 10 & 0 \\
\hline
\end{tabular}

The table above describes that the most problems that cause the taxi drivers do not want to improve their ability can be seen in the point number 1 and 5. From 10 participants it can be seen that 8 drivers did not have a good basic skills of English which become their problems in point number 1 to improve their ability in speaking skills. The working time schedule which is not fit for them to take a course and they think the working time is more important than taking an English course. The time management become the first problems for the drivers to improve their English competency. The others aspect such as the age that decreased learning ability, the ability to use technology as learning media, and also money to take some courses also take more than $50 \%$ as the problems for the drivers.

Based on the problems above and the need analysis, the Hutchinson and Waters model is applied in creating English material which is fit for the taxi drivers. The model proposed by Hutchinson and Waters consists of four elements namely; input, content focus, language focus, and task.

a. Input

The input gathers from various things such as video, dialogue diagram or even a text. Input should be consist of stimulus materials for the activities, new language items, correct models of language use, a topic for communication, opportunities for learners to use their existing knowledge, and opportunities for learners to use their existing knowledge. Input can be in a form of text, diagrams, video, dialogue or anything to provide the stimulus to the learners.

b. Content focus

The primary attention called as the content of the material. The information and feeling about something is a means of language. The content focus should gives explanation to the input given.

c. Language focus

The language focus made the learner enables to use language and to give learners the chance to take the language to pieces, learn how it works and 
practice to put them together. In other words, the language focuses concern with all the analysis of structure as the basis on the content focus.

d. Task

By the task, the learner can use their content and language knowledge. Language competency and improvement is the main purpose of language learning. By giving a task, the learner will have the opportunities to practice what they have learnt and encourage the to improve their skills.

The four elements combine in the model can be seen as visualized figure below:

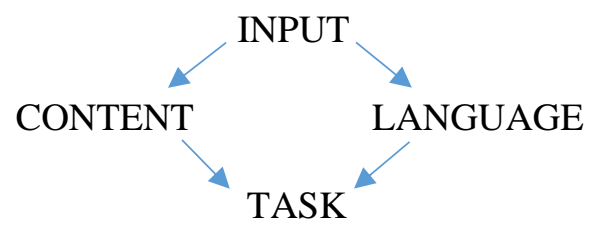

\section{The Oral Discourse Aspects}

According to Wisniewski discourse is originally comes from the word "discursus" which in Latin means conversation or speech (Wisniewski, 2006). According to (Wijana and Rohmadi, 2009: 68) discourse is divided become utterance as a unity and a whole utterance. Discourse can be produced in spoken or written forms but the spoken discourse is a language that uttered by a speaker. The main focus on this research is the oral discourse. The oral discourse is a speech act that is formed by a speaker, and listener to express a talking in any functions such as description, argument, opinion, etc. Besides, oral discourse is a continuous stretch of language larger sentence or narrative in discourse analysis. Discourse analysis is the study of the relationship between the sentences. Discourse analysis plays as a way of understanding social interaction (Fulcher, 2005). Meanwhile Van Dijk said that to analyse the oral discourse, the focus should be on the dynamic aspects of the spontaneous interaction in social science perspective (Van Djik, 2000).

As Van Dijk said that the oral words, sentences or speeches are used in communicative contexts and have specific functions in contexts. Oral discourse is always related with the speech act in meaning interpretation (Van Djik, 1983). Searle distinguishes the speech act into five types in relation with their functions. Those five types are affirmatives or representatives, expressive, directive or appellative, commisive, and declarative (Searle, 1969).

a. Affirmatives or representatives

When the speakers deny something with the affirm as the aim of explaining what is wanted to say or inform. Examples: to agree and to communicate.

b. Expressive

When the speakers show or transmit emotional and affective statement. Examples: expressing compliments, apologies and advises.

c. Directive or appellative

When the speakers persuade the listener to do a specific action and it can be in form of questions, request or imperative. Examples: commands, questions and requests.

d. Commissive

When the speakers assume a commitment independently. The comissive is the acts that the speakers use to commit some future actions and express the speaker intends. Examples:

e. Declarative

When the speaker try to modifying any situation. The speaker has the authority or has an official and public acknowledgment to pronounce some specific words. Examples: policeman, priest, lecturer.

\section{Material Presentation}

Designing the materials was the step after finding all the problems faced by the taxi drivers to improve their competency in English. The presentation of the English material in oral aspects presented briefly as follows:

a. The example of English material for taxi drivers

The materials below based on Hutchinson and Waters' mode consists with input, content focus, language focus and task. The input already consists the stimulus materials for the activities, new vocabulary in English, the correct conversation of language use, and the topic which in line for the taxi driver with the international guest who use English in 
communication. The content and language focus centred on the needs of taxi driver to improve the English competency in tourism aspects. The conversation of English material in oral discourse aspect stated in the dialogue below.

Example (1)

MEET THE GUEST (Bertemu Penumpang)

Guest : Taxi! Taxi!

(Taksi! Taksi!)

Driver : Do you need a transport, Sir/Madam/Miss?

(Apakah anda butuh kendaraan, Tuan/Nyonya/Nona?)

Guest : Yes, sure. (Ya, tentu saja.)

Driver : Where to, Sir/Madam/Miss? (Ke mana, Tuan/Nyonya/Nona?)

Guest : Jalan Kuta Beach (Jalan Kuta Beach)

Driver : Please get in. (Silahkan masuk)

Guest : Is it far from Sanur? (Jauhkah dari Sanur?)

Driver : It will take about an hour. (Kira-kira sekitar satu jam)

Guest : An hour? I am in a hurry now. (Satu jam? Saya sedang terburu buru sekarang.)

Driver : It is the rush hour now, Sir/Madam/Miss. (Sekarang sedang jam sibuk, Tuan/Nyonya/Nona.)

Guest : I see. Oh, begitu.

The conversation above is the represent of input, content focus and language focus. Meanwhile the test which is use to measure the ability of the driver in speaking skills or oral discourse aspect can be interpretated by using fill the blanks to find out the correct answers and then make the role play based on the dialogue. The example of the test can be seen as below.

Example (2)

Please fill the blanks part in the conversation below correctly! After the dialogue filled correctly, please practice the situation with your partner.

Guest : Do you speak English?

Driver :

Guest : How long have you learned English?
Driver :

Guest : Do you take a course?

Driver :

Guest : How about the grammar?

Driver :

b. The speech act in oral discourse English material

Affirmative in the conversation has functions to affirm something with the aim to explain what the speaker wants to say or inform. In this case the example given when the guest agree with the idea proposed by the driver to take another way to avoid the traffic.

Example (3)

Driver : The traffic is so bad due to the accident, I think we need to turn around and take the other way.

Guest : I think so.

Expressive is related with the emotional that express by the speaker. In some cases it can be expressing compliments, advises or apologies. The expressive functions in term of apologies can be seen in the example below when the driver have to say apologies because the car machine is overheat. It was definitely involved the emotion when the driver express his feeling and deliver to the guest.

Example (4)

Guest : What happened?

Driver : I have to pull over, the machine is overheat. I am sorry, Sir.

Directive is the action to persuade the listener in the mean to make the listener to do the specific action. In the example below given in the form of request. When the guest tell the driver to go a little faster and confirm by the driver, it can be said that the conversation is the directive action.

Example (5)

Guest : Can you a little faster, please. I am in hurry.

Driver : Alright, Sir.

Commisive is the act that speakers use to do some future actions. The commisive act can be performed alone by the speaker or in the group. The example can be seen as follows when the guest and the driver both will do the action in the future after they utter it.

Example (6)

Guest : I will call my friend.

Driver : I will turn off the radio. 
Declarative is the declaration by the person who has the authority. In the example below can be seen that the guest who has the authority in that moment declare the driver as a very kind person.

Example (7)

Driver : Here is your wallet mam, you forget it this morning.

Guest : You are very kind.

\section{CONCLUSION}

Based on the result of the analysis, the conclusion is divided into three points. The first one is that the taxi driver need to improve their English proficiency, not only the oral aspect such as pronunciation in speaking but also the other aspects such as grammar, vocabulary, writing and reading aspect. The second on is that the English material was created based on the problems from the taxi driver by using Hutchinson and Waters model which consists of four steps namely input, content focus, language focus and test. These models applied because the model proposed by Hutchinson and Waters were the easiest and suitable learning model for the taxi driver since they offer the best result by their simple model in creating material but also easy to understand. The last one is that the introduction of speech acts in oral discourse also added in the English material with the intention to understand the function in any utterance. The function given based on Searle (1696) that has five types in relation with their functions. Those five types added in the
English material are affirmatives or representatives, expressive, directive or appellative, commisive, and declarative.

\section{REFERENCES}

Fulcher, E. (2005). What is Discourse Analysis. http://eamonfulcher.com/discourse_analy sis.html

Hutchinson, T., \& Waters, A. (1987). English for Spesific Purpose. Cambridge University Press.

Idat, T. F. D. (1994). Wacana Pemahaman dan Hubungan Antarunsur. PT Eresco.

Kamarudin Siti, N. D. M., \& Izehari, Z. (2017). Language needs Analysis: An Initial Investigation on Malaysian Drivers for Alternative Taxi Company. July Press.

Searle, J. R. (1969). A Theory of Speech Acts. Speech Acts, An essay in the philosophy of language.

Suwandi, S. (2008). Serbalinguistik: Mengupas Praktik Berbahasa. UNSSPRESS.

Van Djik, T. . (2000). Cognitive discourse analysis: an introduction 1.

Van Djik, T. A. (1983). Structures and functions of discourse; an interdisciplinary introduction to textlinguistics and discourse studies.

Wijana and Rohmadi. (2009). Analisis Wacana Praktis : Kajian Teor dan Analisis. Yuma Pustaka.

Wisniewski, K. (2006). Discourse Analysis. Anglozof. 